[PT]

\title{
A critical re-evaluation of the Miocene/Pliocene boundary as defined in the Mediterranean
}

\author{
F.J. Hilgen ${ }^{a}$ and C.G. Langereis ${ }^{b}$ \\ a Department of Geology, Institute of Earth Sciences, Budapestlaan 4, 3584 CD Utrecht, The Netherlands \\ ${ }^{b}$ Paleomagnetic Laboratory, Fort Hoofdddijk, Budapestlaan 17, 3584 CD Utrecht, The Netherlands
}

Received January 29, 1993; revision accepted May 14, 1993

\begin{abstract}
A critical re-evaluation of the Miocene/Pliocene $(M / P)$ boundary as defined-informally-in the Mediterranean is presented. We show that ages reported earlier for this boundary (ranging from 4.81 to $4.93 \mathrm{Ma}$ ) do not imply any diachroneity of the basal Zanclean lithohorizon which reflects the Pliocene flooding of the Mediterranean and defines the $M / P$ boundary. These ages most likely represent an artefact resulting from intraformational variations in sedimentation rate and inconsistent interpretation of coluor variations in terms of sedimentary cycles. The best estimate for the age of this boundary arrives at $4.86 \mathrm{Ma}$ if the conventional geomagnetic polarity time scale (GPTS) of Berggren et al. [1] is used, and at $5.16 \mathrm{Ma}$ if the new GPTS of Cande and Kent [2] is used. An age of 5.32 Ma is obtained if the astronomically calibrated time scale of Hilgen [3] is adhered to.

Because of its presumably global paleoclimatological significance, the $\mathrm{M} / \mathrm{P}$ boundary as currently defined in the Mediterranean is preferred to a redefinition of this boundary at the Gilbert/Chron 5 boundary in a continuous open-marine sequence outside the Mediterranean. In addition, this redefinition would lead to unnecessary confusion in global chronostratigraphy.
\end{abstract}

\section{Introduction}

The Miocene/Pliocene boundary and the base of the Zanclean Stage are at present informally defined at the base of the Trubi marl Formation in the Capo Rossello section located in southern Sicily [4,5]. This distinct lithohorizon reflects the re-establishment of open-marine conditions in the Mediterranean following the Messinian salinity crisis at the beginning of the Pliocene [6]. Accurate, first-order age estimates for this horizon have been obtained from several sections other than Capo Rossello and range from 4.81 to 4.93 $\mathrm{Ma}$ [7-9]. All these ages are based on the straightforward calibration of magnetostratigraphic records to the geomagnetic polarity time scale (GPTS) of Berggren et al. ([1], BKFV85) in combination with a downward extrapolation of the sediment accumulation rate and/or the average duration of sedimentary cycles. Despite the small age uncertainty and the fact that the boundary proved to be invariably positioned slightly below the base of the Thvera subchron, two fundamental questions remain to be solved: firstly, were open-marine conditions restored instantaneously, or diachronously as proposed by McKenzie et al. [10]?, and secondly, what is the actual age of the $M / P$ boundary? The small differences in the reported ages could indeed suggest that the basal Zanclean lithohorizonboth in Sicily and in adjacent southern Calabria corresponding to the base of the Trubi marls-is diachronous.

Initial age estimates of 4.83 and $4.84 \mathrm{Ma}$ for the base of the Trubi in southern Calabria [7] were shown to be slightly too young due to a reduction of the sedimentation rate in the basal part of the Trubi. The actual age proved to be 4.86 Ma, exactly the same as found for the base of the Trubi Formation at Eraclea Minoa in Sicily [8]. This age was obtained by downward extrapolation of the average periodicity of approximately $19 \mathrm{kyr}$ for $\mathrm{CaCO}_{3}$ ('limestone-marl') cycles from the lower Thvera reversal boundary to the base of 
the Trubi. On the basis of high-resolution biostratigraphic and cyclostratigraphic correlations, the same age could also be inferred for this lithohorizon at Capo Rossello, and hence for the $\mathrm{M} / \mathrm{P}$ boundary and base of the Zanclean Stage [8].

An age of $4.93 \mathrm{Ma}$ was found for the base of the Trubi at Capo Spartivento in southern Calabria [9]. This age was obtained in the same way as our age estimate of $4.86 \mathrm{Ma}$. The reported number of eight pre-Thvera cycles in the Capo Spartivento section, however, does not agree with the number of five cycles that we found in other Trubi sections, including the proposed boundary stratotype at Capo Rossello [8]. This difference in the number of pre-Thvera cycles almost entirely accounts for the age discrepancy of $70 \mathrm{kyr}$ for the $\mathrm{M} / \mathrm{P}$ boundary (the remaining $10 \mathrm{kyr}$ results from Channell et al.'s preference for an age of 4.78 instead of $4.77 \mathrm{Ma}$ for the lower Thvera reversal boundary). Since these sedimentary cycles are clearly related to the astronomical cycle of precession (see [3] and references cited therein), the various sections should contain the same number of cycles unless the base of the Trubi is timetransgressive or tectonically disturbed. But evidence pointing to syn-sedimentary slumping or post-depositional tectonic erosion has not been observed in the majority of our sections.

We therefore decided to study the Capo Spartivento section of Channell et al. [9] to find out whether the sedimentation of the Trubi started earlier at Capo Spartivento than in the sections we studied. In addition, we sampled the Buonfornello section in northern Sicily to obtain an accurate age estimate for the base of the Pliocene in the Tyrrhenian domain. The synchroneity of this basal Zanclean lithohorizon and the age of the $\mathrm{M} / \mathrm{P}$ boundary will be discussed on the basis of the new results from these sections as well as on the basis of published results from other sections. This discussion is especially relevant in view of the recently advanced proposal to redefine the $\mathrm{M} / \mathrm{P}$ boundary outside the Mediterranean [11], the publication of a new GPTS ([2], CK92) and the establishment of an astronomically calibrated (polarity) time scale (A(P)TS) for the entire Pliocene and early Pleistocene $[3,12,13]$.

\section{The synchroneity of the basal Zanclean litho- horizon}

We have drawn a distinction between Tyrrhenian and western Ionian domains. We will first discuss the Ionian domain, because both the Capo Spartivento section of Channell et al. [9] and our previously studied sections of Singa and Roccella in Calabria [7] and of Eraclea Minoa and Capo Rossello in southern Sicily [8] are located in this area (Fig. 1).

\subsection{Ionian domain}

The Capo Spartivento section of Channell et al. [9] is located along the SS 106 coastal road 5 $\mathrm{km}$ west of Capo Spartivento (Fig. 1), $65 \mathrm{~km}$ southwest of the Singa and Roccella sections studied by Zijderveld et al. [7]. We have established an integrated magnetostratigraphy (examples of thermal demagnetisation diagrams are shown in Fig. 2), planktonic foraminiferal biostratigraphy and lithostratigraphy for this section. Our results are presented in Fig. 3 and compared with similar results from Eraclea Minoa in Sicily.

This comparison reveals that, despite the tectonic deformation at Capo Spartivento (see caption to Fig. 3), the same lithological succession of the Trubi can be recognised and that both geomagnetic reversal boundaries and biostratigraphic events are located in exactly the same sedimentary cycle-as numbered from the base of the Trubi-in both sections (Fig. 3). Most impor-

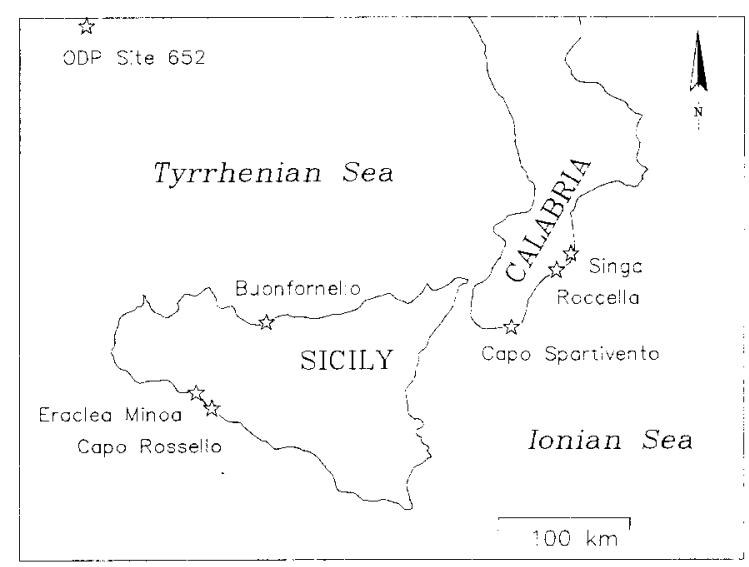

Fig. 1. Location map of the sections used in this paper. 
tantly, our results indicate that the lower Thvera reversal boundary is positioned between the fifth and sixth sedimentary cycle of the Trubi and not between cycles 8 and 9 as suggested by Channell et al. [9]. Consequently, no difference is found in the number of pre-Thvera cycles between this section and other sections of the Trubi. Apparently, the discrepancy in the observed number of pre-Thvera cycles at Capo Spartivento (and hence in the age for the base of the Trubi) between our study and that of Channell et al. [9] represents an artefact which originates from a different interpretation of colour variations in terms of sedimentary cycles.

Sedimentary cycles in the Trubi northeast of Capo Spartivento consist of an indurated, whitish, $\mathrm{CaCO}_{3}$-rich marl bed and a softer, grey, $\mathrm{CaCO}_{3}-$ poor marl bed [7,14]. In Sicily, however, the whitish part of these sedimentary cycles usually contains an additional, beige $\mathrm{CaCO}_{3}$-poor layer [14]. Although less distinct, these beige layers can also be recognized in the majority of the sedimentary cycles at Capo Spartivento. They have been included by Channell et al. [9] in their white ('limestone') beds. These beige layers can in general easily be distinguished from the pronounced grey layers, except in the basal part of the section. In the corresponding basal part of the Trubi in Sicily, four beige layers can easily be identified (Fig. 3, the beige layers of our sedimentary cycles 1, 2, 4 and 6). Careful observation reveals that these beige layers are also present at Capo Spartivento (Fig. 3). Channell et al. [9] most likely interpreted these four beige layers as grey ones (Fig. 4). As a consequence, the Trubi at Capo Spartivento contains five instead of eight pre-

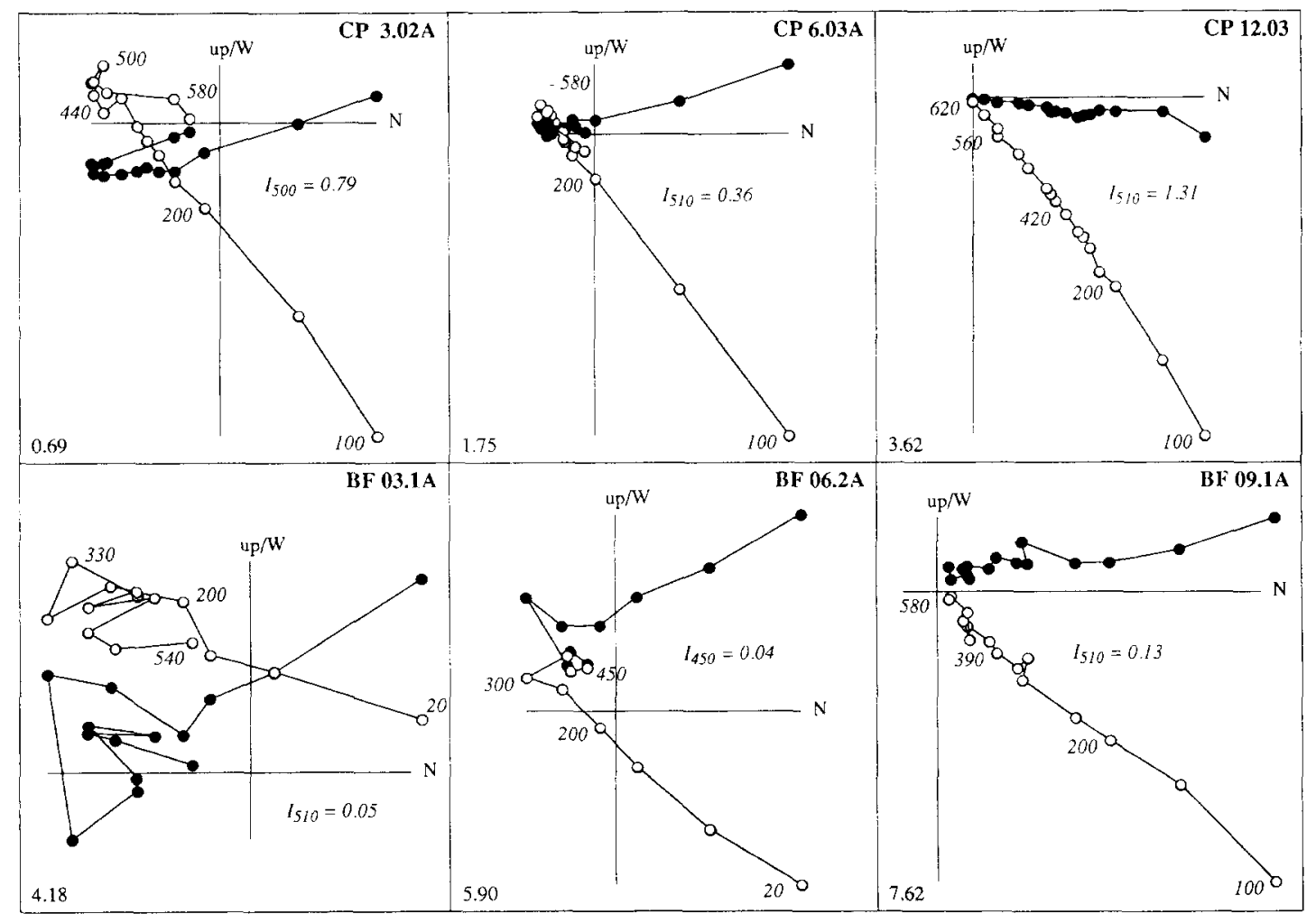

Fig. 2. Thermal demagnetisation diagrams of specimens from Capo Spartivento (CP) and Buonfornello (BF). Solid symbols denote projection on the horizontal plane, open smbols on the vertical plane; numbers refer to demagnetisation temperatures. The intensity at $510^{\circ} \mathrm{C}$ (or the nearest step to it) is given. The stratigraphic levels are printed at the bottom left. Even if intensities are low (BF 03.1A and BF 06.2A) or the secondary overprint very large (CP 6.03A), the polarity-if not always the direction-can be unambiguously established. In general, demagnetisation characteristics are very similar to those found in other Trubi sections [cf. 49], including occasionally high (up to $620^{\circ} \mathrm{C}, \mathrm{CP} 12.03$ ) maximum unblocking temperatures. 


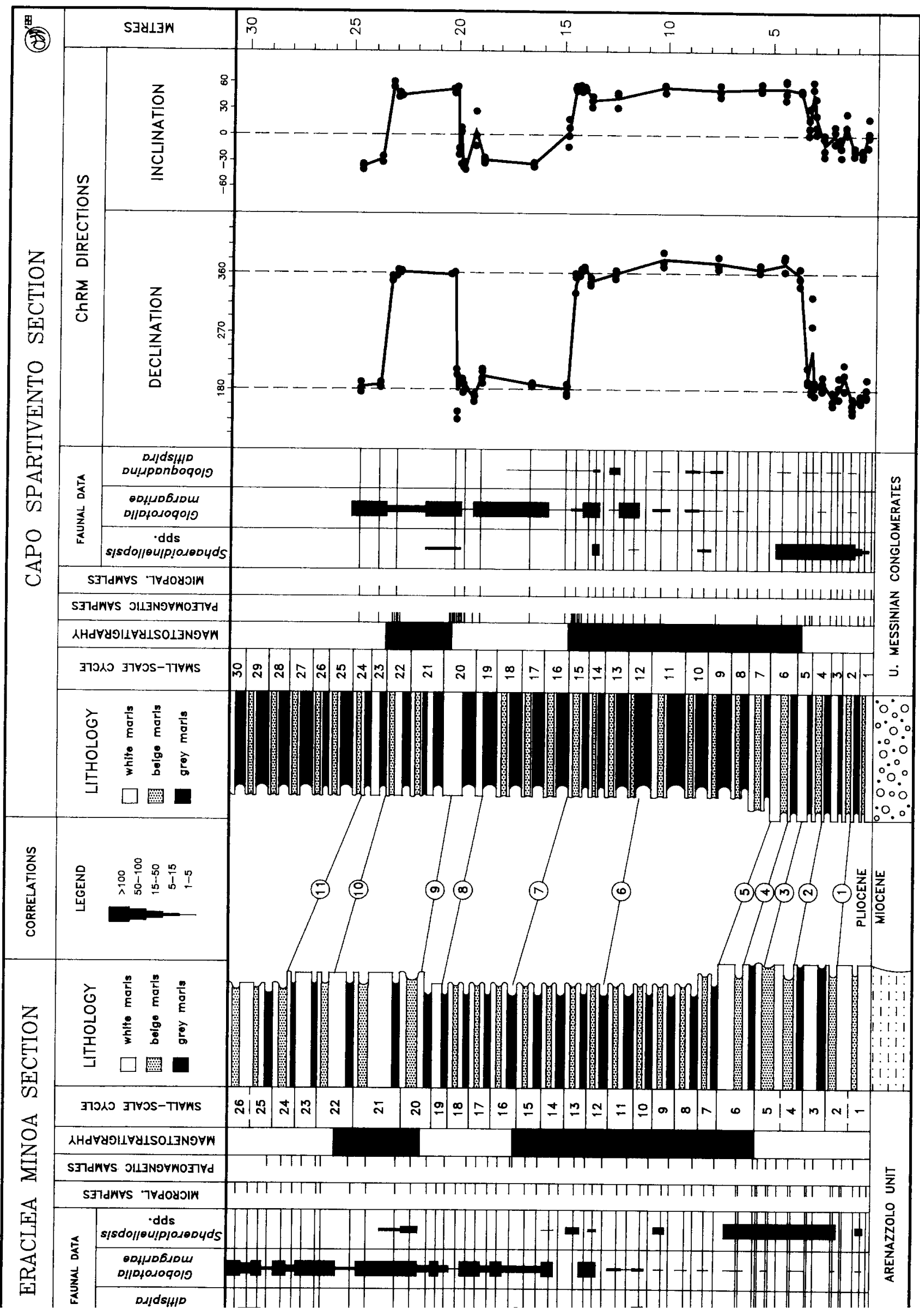


Thvera cycles. This sets the age for the base of the Trubi and hence the $\mathrm{M} / \mathrm{P}$ boundary in this section at $4.86 \mathrm{Ma}$. This is exactly the same age as found in other Trubi sections, both in Sicily and in Calabria. In conclusion, the age of the basal Zanclean lithohorizon in the western Ionian domain is $4.86 \mathrm{Ma}$.

\subsection{Tyrrhenian domain}

We initially focused our attention on ODP Leg 107 , which was dedicated entirely to the study of the Tyrrhenian Basin [15]. Of all the sites that penetrated the Miocene, only Site 652 contains an apparently complete basal Pliocene succession [16]. A first approximation of $4.85 \pm 0.01 \mathrm{Ma}$ for the age of the basal Pliocene lithohorizon at this site is obtained by downward extrapolation of the Thvera sedimentation rate [17]. Unfortunately, there is no distinct cyclic bedding to constrain this age more precisely and to prove whether open-marine conditions were restored synchronously in the Tyrrhenian and Ionian realm. Nevertheless, the $40 \mathrm{~cm}$ thick transitional interval at Site 652 corresponds $[15,16]$ remarkably well to a similar and equally thick interval at Eraclea Minoa (described in detail by Brolsma [18] and confirmed by our own field observations).

We incorporated the Buonfornello section in this study to determine whether there is a Tyrrheno-Ionian synchroneity of the basal Pliocene lithohorizon. The Buonfornello section is located in northern Sicily (Fig. 1) and consists of several subsections exposed along the River Imera $[5,19,20]$. We have sampled only the lowermost subsection (Buonfornello 1 of de Visser [20]). In this section, basal Pliocene sediments of the Trubi sharply overlie sands and fine conglomerates of the Messinian. These Trubi marls were deposited in a small subbasin of the larger Cefalu Basin located along the northern margin of the Calabro-Sicilian Arc. This basin started to develop during the (late) Tortonian and was constantly part of the (proto-)Tyrrhenian realm [2124].

The recognition of the characteristic cycle pattern at Buonfornello demonstrates that, here too, the basal part of the Trubi is as complete as in the other Trubi sections (Figs. 5 and 6). This is confirmed both by biostratigraphic data-showing that the characteristic interval preceding the Sphaeroidinellopsis acme s.s. is present-and by magnetostratigraphic data-revealing a polarity transition from reversed to normal between the fifth and sixth sedimentary cycle (Figs. 2, 5 and $6)$.

\section{Age of the $M / P$ boundary}

\subsection{Conventional age}

Summarising, the basal Zanclean lithohorizon has exactly the same age-4.86 Ma-in the Tyrrhenian and in the western Ionian domain of the Mediterranean, implying that open-marine conditions were restored simultaneously in these

Fig. 3. Magnetostratigraphy, biostratigraphy and lithostratigraphy of the Trubi in the Capo Spartivento and Eraclea Minoa sections. The Trubi at Capo Spartivento is tectonically disturbed but this deformation (shear planes in grey layers) has not been indicated. Stratigraphic data from Eraclea Minoa are based on Hilgen and Langereis [8]. Thermal demagnetization of the Trubi at Capo Spartivento gives essentially the same results as given by Channell et al. [9]. Declination and inclination of ChRM show considerable scatter in several intervals due to a large secondary overprint: reversed polarity components are sometimes only revealed at temperatures higher than $450-500^{\circ} \mathrm{C}$. Nevertheless, the polarity and hence the magnetostratigraphy is well defined. Moreover, the polarity reversals are located in exactly the same sedimentary cycles as found earlier in other Trubi sections [7,8,50]. The two normal polarity intervals shown represent the Thvera and Sidufjall Subchrons [see 7] and the position of the upper Thvera reversal boundary at Eraclea Minoa has been slightly revised based on new data [51]. The upper Thvera boundary is now pinpointed in the lower part of cycle 16 and the lower Thvera at the transition from cycle 5 to cycle 6 . The intermediate directions initially observed within cycle 15 are now interpreted as a sedimentary artefact resulting from delayed acquisition of remanent magnetisation [51]. Sedimentary cycles have been numbered from the base of the Trubi upward [after 52]. Cycle 21 clearly is a double cycle at Capo Spartivento. This observation accords with previous suggestions [3,52]. Semi-quantitative faunal data are based on surveying one picking tray containing 10,000-15,000 specimens. Numbered stratigraphic correlations refer to (1) base beige marl of cycle 2, (2) base beige marl of cycle 4, (3) lower Thvera reversal boundary, (4) base beige marl of cycle 6 , (5) top of cycle 6 and of the Sphaeroidinellopsis acme, (6) first substantial increase in G. margaritae, (7) upper Thvera, (8) top of thin cycle 19, (9) lower Sidufjall, (10) upper Sidufjall, and (11) base distinct beige marl of cycle 24. 


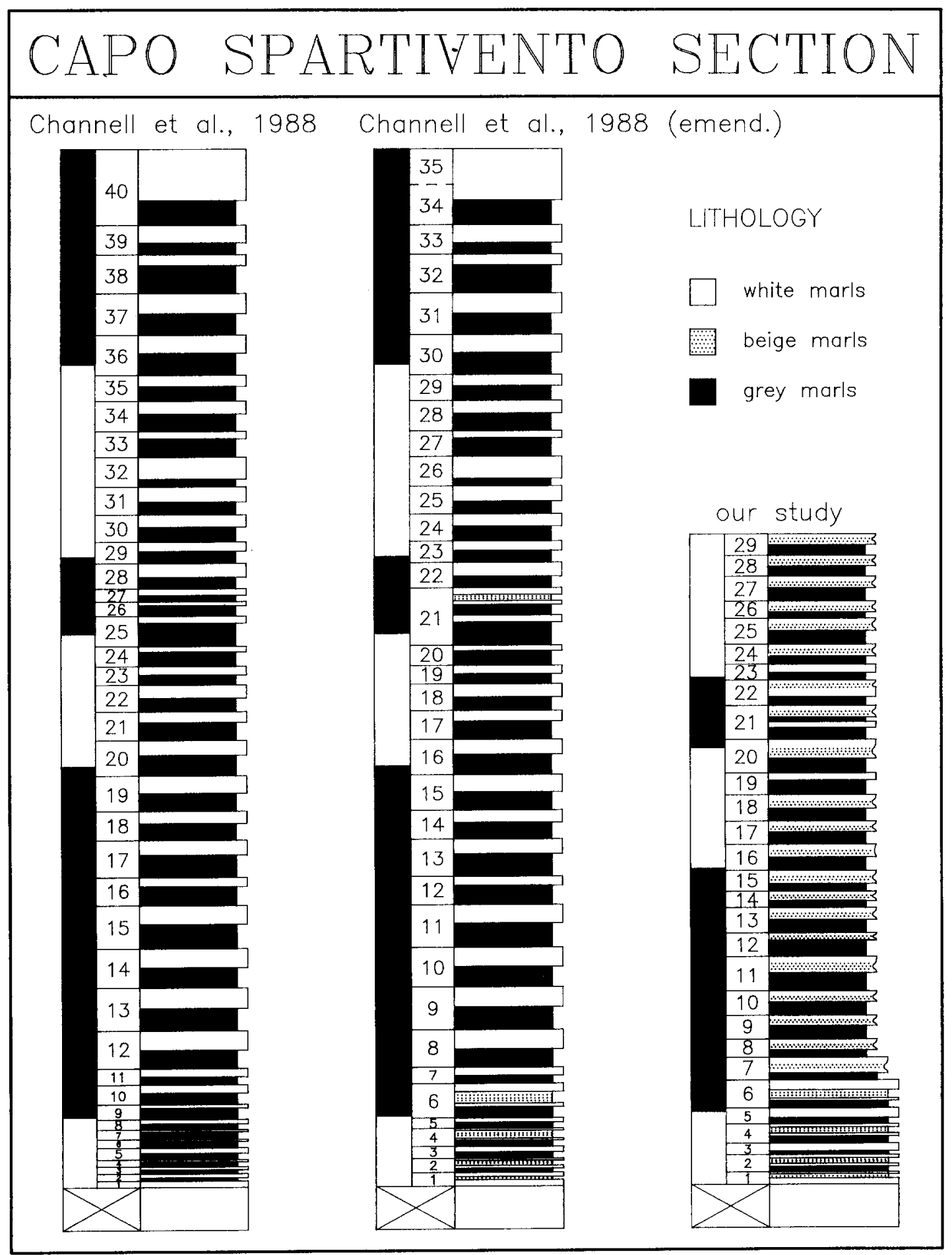

Fig. 4. Magnetostratigraphy and cyclostratigraphy of the Capo Spartivento section according to Channell et al. ([9], log A) and this study $(\log C)$. In $\log$ B, the cyclostratigraphy of Channell et al. [9] has been amended to match our observations, assuming that they misinterpreted the beige-coloured layers of cycles $1,2,4,6$ and 21 as grey layers. 


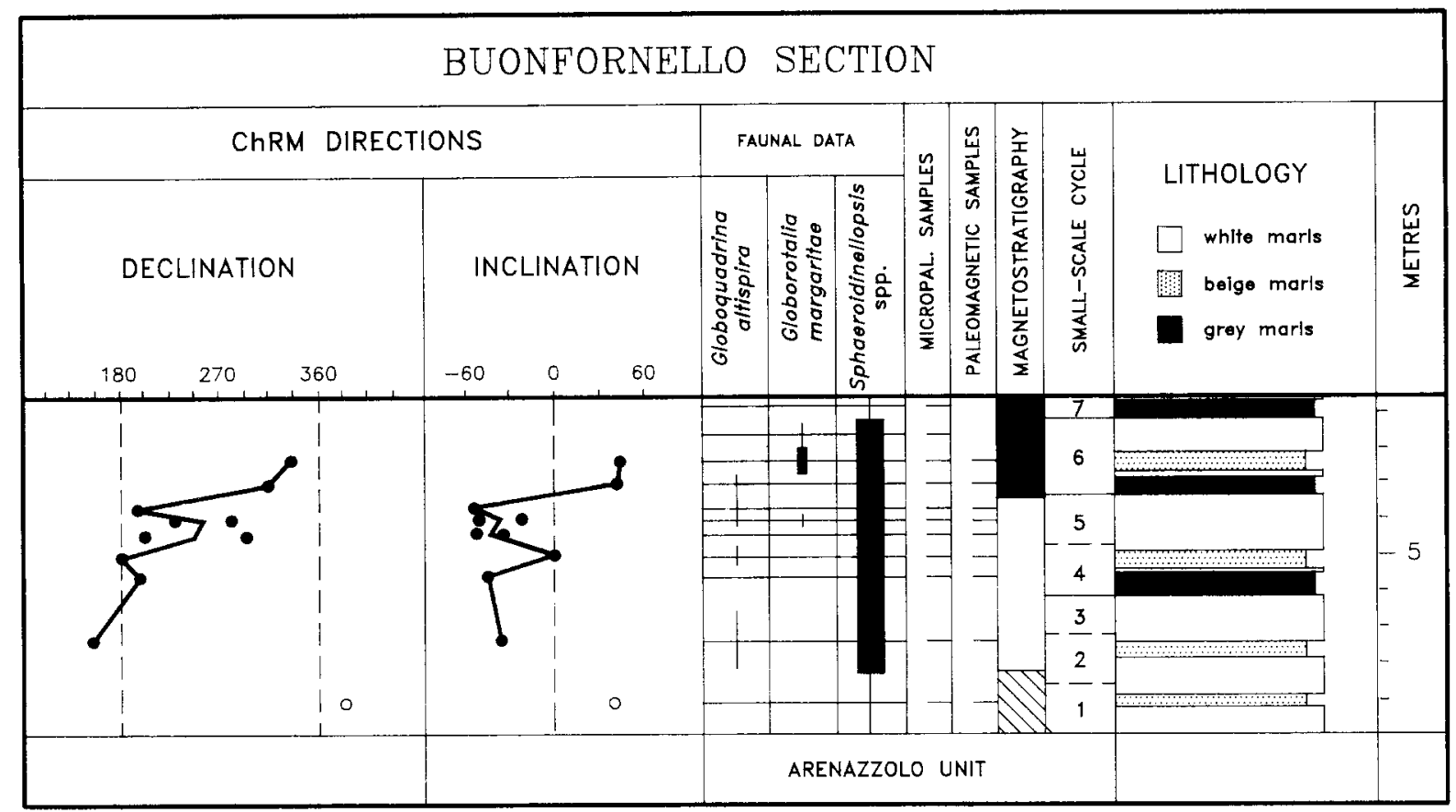

Fig. 5. Magnetostratigraphy, biostratigraphy and cyclostratigraphy of the Buonfornello section in northern Sicily. See caption to Fig. 3.

areas at the beginning of the Pliocene. This age is obtained by extrapolating the average periodicity of $18.9 \mathrm{kyr}$ of the $\mathrm{CaCO}_{3}$ cycles from the lower Thvera reversal boundary with an age of $4.77 \mathrm{Ma}$ -in BKFV85-down to the base of the Trubi [8]. Based on the detailed lower Thvera reversal record from Eraclea Minoa [25], we presently prefer to use 5 instead of the 4.66 pre-Thvera cycles used by Hilgen and Langereis [8].

But a new GPTS has recently been established based on a new and comprehensive analysis of marine magnetic anomaly profiles from the world's ocean basins (CK92 of Cande and Kent [2]). Application of CK92 results in an age of 5.16 $\mathrm{Ma}$ for the $\mathrm{M} / \mathrm{P}$ boundary if the procedure outlined above is followed (average periodicity of $\mathrm{CaCO}_{3}$ cycles is $22.2 \mathrm{kyr}$ according to CK92). The main reason for the age difference is the age of 5.046 Ma for the lower Thvera reversal boundary in CK92. The discrepancy between CK92 and BKFV85 stems partly from the fact that Cande and Kent [2] incorporated an astronomical calibration point, the Gauss / Matuyma dated at 2.60 Ma [12,13], in their analysis.

\subsection{Astronomical age}

The $M / P$ boundary would now seem to be very accurately dated because the existing range in age estimates-from 4.81 to $4.93 \mathrm{Ma}$-for the restoration of open-marine conditions in the Mediterranean following the Messinian salinity crisis has been merged into a single consistent age of $4.86 \mathrm{Ma}$. This age is obtained if the BKFV85 time scale is applied, but application of CK92 results in an age of $5.16 \mathrm{Ma}$. Since the $\mathrm{CaCO}_{3}$ cycles in the Trubi have been related explicitly to the astronomical cycle of precession ([3] and references therein), it would at this point be more correct to state that the $\mathrm{M} / \mathrm{P}$ boundary is $5 \times 21 \mathrm{kyr}$ older than the lower Thvera reversal boundary, 5 being the number of pre-Thvera cycles and 21 the average periodicity of the precession cycle in kyr. This alternative approach would result in $\mathrm{M} / \mathrm{P}$ boundary ages of 4.88 instead of $4.86 \mathrm{Ma}$, and 5.15 instead of $5.16 \mathrm{Ma}$ if the BKFV85 and CK92 scales are taken respectively.

An astronomically calibrated (polarity) time scale has been constructed for the entire Pliocene 


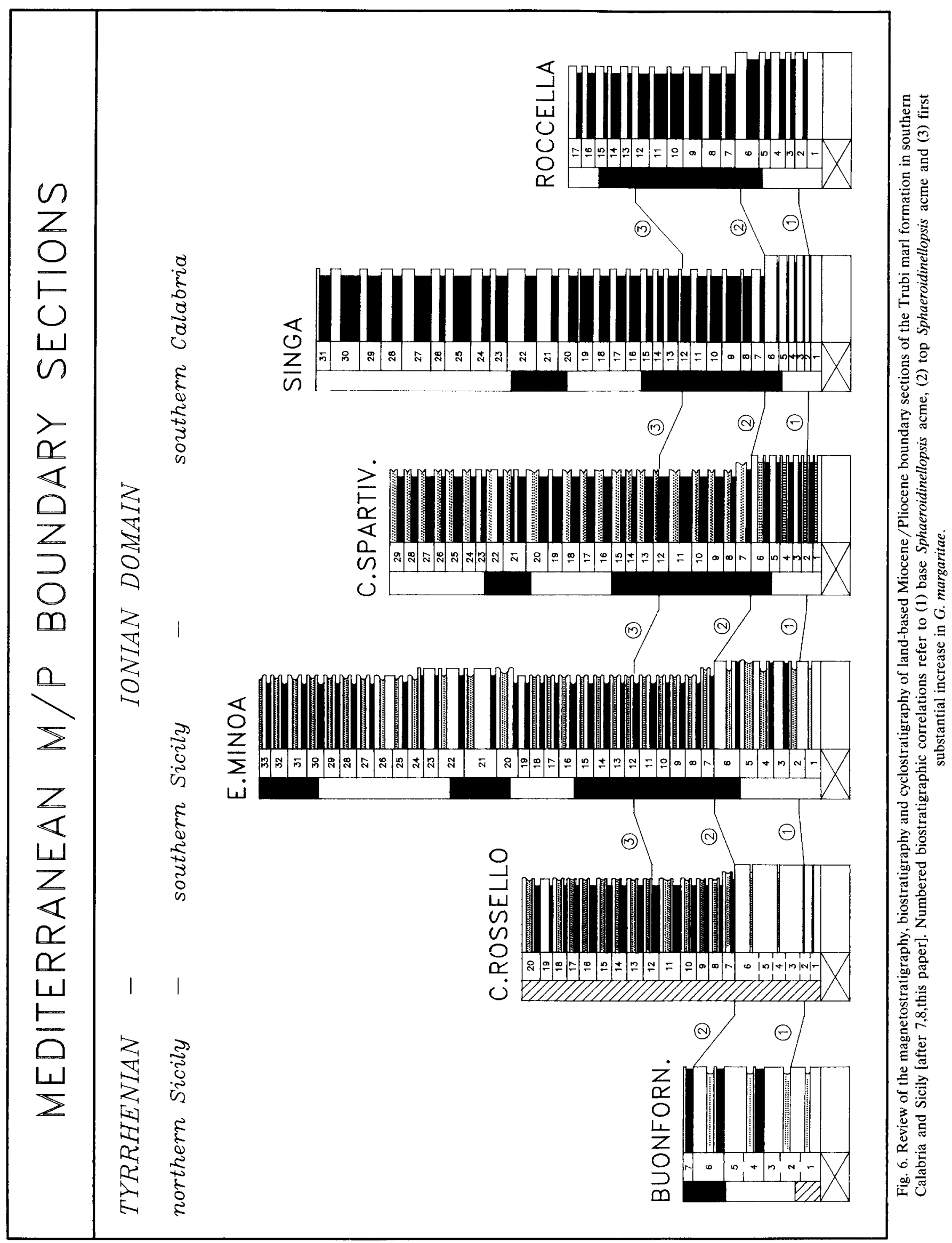


$[3,13]$. This time scale is based on the correlation of sedimentary cycles in Mediterranean deep-sea sequences, including the $\mathrm{CaCO}_{3}$ cycles of the Trubi, to the astronomical solution [26,27]. It results in an astronomically calibrated age of 5.32 $\mathrm{Ma}$ for the base of the Trubi and hence for the $\mathrm{M} / \mathrm{P}$ boundary [3]. This age is supposed to represent a more accurate and definitive age for the $\mathrm{M} / \mathrm{P}$ boundary (as defined by the base of the Zanclean) because the astronomical solution is considered accurate in the time domain over the last 5 myr [26] and the astronomical calibration has been independently confirmed in a number of extra-Mediterranean sequences [12,28].

\section{The desirability of redefining the $M / P$ bound- ary}

The once controversial chronostratigraphy of the $\mathrm{M} / \mathrm{P}$ boundary as informally defined at the base of the Trubi marls at Capo Rossello has now been well established. The best estimates for the age of this boundary arrive at 4.86 and $5.16 \mathrm{Ma}$ if the BKFV85 and CK92 time scales, respectively, are used, and at $5.32 \mathrm{Ma}$ if the astronomically calibrated time scale is used. This reduces the necessity to redefine the $\mathrm{M} / \mathrm{P}$ boundary outside the Mediterranean. The most recently advanced proposal is that of Benson et al. [11], who suggest a level at $32 \mathrm{~m}$ in the Ain al Beida section in Atlantic Morocco. This specific level coincides with the Gilbert/Chron 5 boundary, probably prompted by the common practise of positioning the $\mathrm{M} / \mathrm{P}$ boundary at or close to this reversal before a first and reliable age estimate was established for the $\mathrm{M} / \mathrm{P}$ boundary in the Mediterranean [7]. The main reason for this redefinition is that the Capo Rossello section fails to meet the operational requirements of a Global Section Boundary Stratotype and Point (GSSP).

One of the main arguments is that the boundary is defined at an unconformity which separates open-marine Trubi marls from the underlying Arenazzolo Formation of latest Messinian age. This unconformity has been interpreted as an erosional surface [4,5], but no clear evidence for the presence of such an unconformity is found at Eraclea Minoa. On the contrary: a $30-40 \mathrm{~cm}$ thick transitional interval suggests that subaquous conditions persisted across the $M / P$ boundary and resulted in an apparently continuous sedimentation [see also 18], although Cita and Colombo [29] suggest that this interval represents an artefact resulting from burrowing-induced mixing of the lithologies. The interpretation of a transitional interval is consistent with the lateral continuity of the boundary at Eraclea Minoa. It is also in agreement with results obtained from ODP Leg 107 in the Tyrrhenian, which showed that a similar and equally thick transitional interval was recovered at the site (Site 652) containing the most complete basal Pliocene. This transitional interval has been interpreted in the same way [16] that we interpret this interval at Eraclea Minoa. On the other hand, a distinct unconformity is present at the boundary stratotype section of Capo Rossello, but we disagree with Cita and Gartner [4] that it represents an erosional surface. The local contact between Arenazzolo and Trubi sediments is tectonically disturbed [30, plate 2; see also fig. 6 in 4], probably due to gravitational sliding which affected the sharp lithological conatact between the indurated Trubi marls and the softer, more clayey sediments of the Arenazzolo.

In summary, no indications have been found for the presence of an unconformity at the sites which provide the most detailed picture of the $\mathrm{M} / \mathrm{P}$ boundary transition, i.e. ODP Site 652 and Eraclea Minoa. A tectonically controlled unconformity is present at Capo Rossello and this makes the Eraclea Minoa section more suitable for defining the $\mathrm{M} / \mathrm{P}$ boundary than Capo Rossello [see also 8]. It also invalidates one of the main arguments-the unconformity-for redefinition of the boundary outside the Mediterranean.

Other arguments for redefining the $M / P$ boundary outside the Mediterranean are that the boundary is not positioned in a continuous openmarine succession, that it will not permit a precise biostratigraphic designation, and that it will preclude the recognition of a sequence of events directly prior to it $[11,31-33]$. It is further argued that boundary stratotypes should not be tied to local events which may not be correlated globally [31]. Maintaining the current position of the $\mathbf{M} / \mathbf{P}$ boundary implies that the latest Miocene (Messinian) represents an interval which is marked both by heavy $\delta^{18} \mathrm{O}$ values and by high-frequency and high-amplitude variations in $\delta^{18} \mathrm{O}$ [34-38]. 
This pattern has been related to a series of rather well-defined glacial-interglacial cycles preceding a prolonged period of warmer conditions in the early Pliocene. The last full glacial maximum of this series of latest Miocene ice volume changes has been dated at approximately $4.9 \mathrm{Ma}[35,37,38]$ and is accompanied by a glacioeustatic sea-level lowering of at least $60 \mathrm{~m} \mathrm{[37].}$

Many authors presently favour a causal connection between global glacioeustatic sea-level changes and sequence stratigraphic events in the Mediterranean Messinian, but the exact timestratigraphic correlations are still a matter of debate [e.g., 35,38]. In this view, the accurate conventional dating of the basal Zanclean lithohorizon at $4.86 \mathrm{Ma}$ indeed suggests that the reestablishment of open-marine conditions in the Mediterranean is coincident with the termination of the last full glacial maximum of Messinian affinity and that the accompanying rise in sea level is at least partly responsible for the Pliocene flooding of the Mediterranean [8]. Hence, there is growing evidence that the restoration of openmarine conditions in the Mediterranean at the beginning of the Pliocene is of global significance and that it can be correlated worldwide. This correlation certainly needs confirmation, preferably by means of high-resolution cyclostratigraphic correlations to well-dated extra-Mediterranean stable isotope records. Such an approach may in addition reveal how the Messinian evaporites in the Mediterranean are related to paleoclimatic and paleoceanographic changes elsewhere.

According to a tentative scenario, the transition between the Lower and Upper Evaporites (stratigraphic nomenclature after [39]) would correspond to the full glacial maximum dated around 5.2 $\mathrm{Ma}$ in the open ocean [37,40] and the Arenazzolo unit, which lies on top of the Upper Evaporites and precedes the marls of the Trubi, to the full glacial maximum dated around $4.9 \mathrm{Ma}[37,41]$. The six to seven evaporite cycles of the Upper Evaporites would then exactly match the number of obliquity-related cycles between the two full glacial maxima in the $\delta^{18} \mathrm{O}$ record from DSDP Site 552 [see 40]. These cycles may reflect rather weak glacial cycles, as indicated by the reduced magnitude of the isotope shifts and the reduction in the amplitudinal variations of the filtered 41 kyr component in the $\delta^{18} \mathrm{O}$ record. The associ- ated minor sea-level falls would also allow Atlantic waters to invade the Mediterranean during glacial times. But an alternative option would be that the evaporite cycles are connected with regional climatic oscillations related to the precession cycle rather than to obliquity. This scenario demonstrates the potential of high-resolution cyclostratigraphic correlations in solving time-stratigraphic relationships in the $\mathrm{M} / \mathrm{P}$ boundary interval. It is evident from this approach that arguments that suggest that the $\mathrm{M} / \mathrm{P}$ boundary is not defined in a continuously open-marine sequence or that it precludes the recognition of events directly preceding the boundary will be either reduced to a formal restriction or will be invalidated once a tight cyclostratigraphic framework has been established for the latest Miocene. In view of recent developments in establishing such a framework for the Pliocene $[3,12,13,42-44]$, we foresee that a similar framework will be established for the latest Miocene in the near future. The $\mathrm{M} / \mathrm{P}$ boundary should be tied directly into such a framework because this would allow the boundary to be accurately dated by means of astronomical calibration. Evidently, these conditions are already fulfilled in the case of the $\mathrm{M} / \mathrm{P}$ boundary definition in the Mediterranean being maintained [3].

Biostratigraphic recognition of the $\mathrm{M} / \mathrm{P}$ boundary as defined in the Mediterranean is rather poor [see 33] probably because the boundary is coincident with the beginning of a prolonged period of warmer conditions. The first occurrence of Ceratolithus acutus $6 \mathrm{~m}$ above the base of the Trubi at Capo Rossello [4] provides the only useful criterion for biostratigraphic nannofossil correlation to the open ocean, but unfortunately this marker species is extremely rare in Mediterranean Pliocene sections [45,46]. Like in the open ocean [33], it coincides closely with the lower Thvera reversal boundary. Additional evidence for this synchroneity is provided by the presence of rare Triquetrorhabdulus rugosus in the basal 3-4 $\mathrm{m}$ of the Trubi in the Capo Rossello section $[46,47]$. The use of planktonic foraminifera in distinguishing the $\mathrm{M} / \mathrm{P}$ boundary biostratigraphically is even more limited. The first occurrence of Globorotalia margaritae is clearly delayed with respect to the open ocean [7]. Moreover, this species proved to be rare and discontin- 
uously present from the $\mathrm{M} / \mathrm{P}$ boundary onward [8]. In addition, the presence of Sphaeroidinella dehiscens $12 \mathrm{~m}$ above the base of the Trubi at Capo Rossello has never been confirmed by later observations [e.g., 46]. Nevertheless, samples with dominantly left coiling neogloboquadrinids are found in the lowermost $2.5 \mathrm{~m}$ of the Trubi at Eraclea Minoa, well above a sinistral to dextral coiling shift recorded in the adjacent northern Atlantic Ocean and dated around 5.5 Ma [31]. This coiling shift, however, does not occur instantaneously but takes place over an interval of more than $0.5 \mathrm{~m} . y$. (from approximately 5.5 to $4.9 \mathrm{Ma}$ ), during which the coiling ratio changes repeatedly $[41,48]$. The left coiling interval in the Trubi most probably correlates with the last occurrence of dominantly sinistrally coiled neogloboquadrinids in the northern Atlantic. Unfortunately, the resolution of the coiling ratio record of Site 552 is at present too low $( \pm 40 \mathrm{kyr})$ to establish reliably the position of this biohorizon with respect to the prominent changes in $\delta^{18} \mathrm{O}$.

Finally, in the proposal of Benson et al. [11] the $\mathrm{M} / \mathrm{P}$ boundary would be rather arbitrarily defined in the middle part of the characteristic interval of Messinian affinity. This redefinition would in addition lead to an unwarranted state of confusion in global chronostratigraphy. The Upper Evaporites and the Arenazzolo, and probably part of the Lower Evaporites of the classical Messinian in the Mediterranean, will henceforth belong to the Pliocene, but since they are by definition excluded from the Zanclean (the lowermost stage of the Pliocene), either the base of the Zanclean must be redefined to include these formerly Messinian units, or a new global stage must be introduced. The exclusion of the evaporites especially from the Messinian and their possible incorporation in the Zanclean runs counter to the conventional use of these stages and should thus be avoided. In other words, the proposed redefinition would result in a Pliocene 'salinity crisis' in the Mediterranean.

\section{Conclusions}

The range in age estimates (from 4.81 to 4.93 Ma) recently obtained for the basal Zanclean lithohorizon in the Mediterranean and, hence, for the $M / P$ boundary, does not imply that open-marine conditions were restored diachronously in the Mediterranean following the Messinian salinity crisis but represents an artefact which mainly originates from intraformational variations in sedimentation rate and a different interpretation of colour variations in terms of precession-controlled sedimentary cycles.

The Pliocene flooding event is dated as accurately as possible at $4.86 \mathrm{Ma}$ if the conventional BKFV85 time scale is used, and at $5.16 \mathrm{Ma}$ if the new CK92 scale is used. An age of $5.32 \mathrm{Ma}$ is obtained if the astronomically calibrated time scale [3] is followed.

The current $\mathrm{M} / \mathrm{P}$ boundary is probably coincident with the termination of the last full glacial maximum in the glacial series of the Messinian. The boundary is in that case of global significance and can be correlated worlwide.

Biostratigraphic recognition of this boundary on a global scale is rather poor. Nevertheless, the first occurrence of $C$. acutus - in combination with the last occurrence of $T$. rugosus-remains a useful criterion. Another biostratigraphic tool for accurate correlation, at least to the adjacent northern Atlantic Ocean, is provided by the presence of dominantly sinistrally coiled assemblages of neogloboquadrinids in the basal part of the Mediterranean Pliocene.

As a consequence, a definition of the $M / P$ boundary based on the basal Zanclean lithohorizon in the Mediterranean is to be preferred to a redefinition of this boundary at the Gilbert/ Chron 5 boundary reversal in a continuous marine section outside the Mediterranean as proposed by Benson et al. [11]. Such a redefinition would lead to an unwarranted state of confusion in global chronostratigraphy.

\section{Acknowledgements}

H.J. Meijer and P.J. Verplak measured the paleomagnetism of the samples. W.A. Berggren, M.B. Cita, G.B Vai and an anonymous referee are thanked for their critical reviews.

\section{References}

1 W.A. Berggren, D.V. Kent, J.J. Flynn and J.A. van Couvering, Cenozoic geochronology, Geol. Soc. Am. Bull. 96, 1407-1418, 1985. 
2 S.C. Cande and D.V. Kent, A new geomagnetic polarity time scale for the late Cretaceous and Cenozoic, J. Geophys. Res. 97, 13917-13951, 1992.

3 F.J. Hilgen, Extension of the astronomically calibrated (polarity) time scale to the Miocene/Pliocene boundary, Earth Planet. Sci. Lett. 107, 349-368, 1991.

4 M.B. Cita and S. Gartner, The stratotype Zanclean. Foraminiferal and nannofossil biostratigraphy, Riv. Ital. Paleontol. 79, 503-558, 1973.

5 M.B. Cita, The Miocene-Pliocene boundary: history and definition, in: Late Neogene Epoch Boundaries, T. Saito and L.H. Burckle, eds., Micropaleontology Spec. Publ. 1, 1-30, 1975 .

6 K.J. Hsü, M.B. Cita and W.B.F. Ryan, The origin of the Mediterranean evaporites, Init. Rep. DSDP 13, 1203-1231, 1973.

7 J.D.A. Zijderveld, W.J. Zachariasse, P.J.J.M. Verhallen and F.J. Hilgen, The age of the Miocene-Pliocene boundary, Newslett. Stratigr. 16, 169-181, 1986.

8 F.J. Hilgen and C.G. Langereis, The age of the MiocenePliocene boundary in the Capo Rossello area (Sicily), Earth Planet. Sci. Lett. 91, 214-222, 1988.

9 J.E.T. Channell, D. Rio and R.C. Thunell, Miocene/ Pliocene boundary magnetostratigraphy at Capo Spartivento, Calabria, Italy, Geology 16, 1096-1099, 1988.

10 J.A. McKenzie, D. Eiermann, K.J. Hsü, J.E.T. Channell, D.W. Mueller, P.A. Mueller, S.C. Palmer and R. Sprovieri, Stepwise eastward infilling of the earliest Pliocene Mediterranean basins, Terra Abstr. 1, 35, 1989.

11 R.H. Benson, K. Rakic-El Bied, G. Bonaduce, D.A. Hodell, W.A. Berggren, M.-P. Aubry, G. Napoleone and D.V. Kent, A proposal for the Pliocene global boundary stratotype section and point: Bou Regreg section, Morocco, IX RCMNS Congr. Barcelona, Abstr. Vol., p. 57, 1990.

12 N.J. Shackleton, A. Berger and W.R. Peltier, An alternative astronomical calibration of the Lower Pleistocene time scale based on ODP Site 677, Trans. R. Soc. Edinb. 81, 251-261, 1990.

13 F.J. Hilgen, Astronomical calibration of Gauss to Matuyama sapropels in the Mediterranean and implication for the geomagnetic polarity time scale, Earth Planet. Sci. Lett. 104, 226-244, 1991.

14 F.J. Hilgen, Sedimentary rhythms and high-resolution chronostratigraphic correlations in the Mediterranean Pliocene, Newslett. Stratigr. 17, 109-127, 1987.

15 K.A. Kastens, J. Mascle et al., Proc. ODP, Sci. Results $107,1990$.

16 J.A. McKenzie and R. Sprovieri, Paleoceanographic conditions following the earliest Pliocene flooding of the Tyrrhenian Sea, Proc. ODP, Sci. Results 107, 405-414, 1990.

17 J.E.T. Channell, M. Torii and T. Hawthorne, Magnetostratigraphy of sediments recovered at sites 650,651 , 652, and 654 (Leg 107, Tyrrhenian Sea), Proc. ODP, Sci. Results 107, 335-359, 1990.

18 M.J. Brolsma, Quantitative foraminiferal analysis and environmental interpretation of the Pliocene and topmost Miocene on the south coast of Sicily, Utrecht Micropaleontol. Bull. 18, 159 pp., 1978.
19 A. Vismara Schilling and H. Stradner, I 'Trubi' di Buonfornello (Sicilia). Biostratigrafia e tentativo di valutazione paleoclimatica, Riv. Ital. Paleontol. 83, 869-896, 1977.

20 J.P. De Visser, Clay mineral stratigraphy of Miocene to recent marine sediments in the central Mediterranean, Geol. Ultraiectina 75, 244 pp., 1991.

21 A. Barone, A. Fabbri, S. Rossi and R. Sartori, Geological structure and evolution of the marine areas adjacent to the Calabrian arc, Earth Evolut. Sci. 3, 207-221, 1982.

22 I. Finetti and A. Del Ben, Geophysical study of the Tyrrhenian opening, Boll. Geofis. Teor. Appl. 28, 75-155, 1986.

23 G. Sestini and G. Flores, Petroleum potential of the thrust belt and foretroughs of Sicily, in: Future Petroleum Provinces of the World, M.T. Halbouty, ed., AAPG Mem. 40, 567-584, 1986.

24 J.P. Rehault, E. Moussat and A. Fabbri, Structural evolution of the Tyrrhenian back-arc basin, Mar. Geol. 74, 123-150, 1987

25 A.A.M. Van Hoof and C.G. Langereis, The upper and lower Thvera sedimentary geomagnetic reversal records from southern Sicily, Earth Planet. Sci. Lett. 114, 59-75, 1992.

26 A. Berger and M.F. Loutre, Insolation values for the climate of the last 10 m.y., Quat. Sci. Rev. 10, 297-317, 1991.

27 J. Laskar, Secular evolution of the solar system over 10 million years, Astron. Astrophys. 198, 341-362, 1988.

28 R. Tiedemann, M. Mudelsee, M. Sarnthein and K. Stattegger, Astronomical tuning of high-resolution benthic $\delta^{18} \mathrm{O}$ records from ODP Sites 658 and 659 for the last 5 million years vs. non-linear climatic dynamics, 4th Int. Conf. Paleoceanogr., Abstr. Vol., p. 282, 1992.

29 M.B. Cita and L. Colombo, Sedimentation in the latest Messinian at Capo Rossello (Sicily), Sedimentology 26, 497-522, 1979.

30 M.J. Brolsma, Lithostratigraphy and foraminiferal assemblages of the Miocene-Pliocene transitional strata of Capo Rossello and Eraclea Minoa (Sicily, Italy), Proc. Kon. Ned. Akad. Wetensch. B23, 341-380, 1975.

31 D.A. Hodell, R.H. Benson, J.P. Kennett and K. Rakic-El Bied, Stable isotope stratigraphy of latest Miocene sequences in northwest Morocco: the Bou Regreg section, Paleoceanography 4, 467-482, 1989.

32 D. Rio, R. Sprovieri and R. Thunell, Pliocene-Pleistocene chronostratigraphy: a re-evaluation of Mediterranean type sections, Geol. Soc. Am. Bull. 103, 1049-1058, 1991.

33 W.A. Berggren, Neogene planktonic foraminiferal biostratigraphy of eastern Jamaica, in: Biostratigraphy of Jamaica, R.M. Wright and E. Robinson, eds., Geol. Soc. Am. Mem. 182, 1993.

34 C.G. Adams, R.H. Benson, R.B. Kidd, W.B.F. Ryan and R.C. Wright, The Messinian salinity crisis and evidence of late Miocene eustatic changes in the world ocean, Nature 269, 383-386, 1977.

35 D.A. Hodell, K.M. Elmstrom and J.P. Kennett, Latest Miocene benthic $\delta^{18} \mathrm{O}$ changes, global ice volume, sea lével and the 'Messinian salinity crisis', Nature 320, 411414, 1986.

36 D.A. Hodell and J.P. Kennett, Late Miocene-early 
Pliocene stratigraphy and paleoceanography of the South Atlantic and southwest Pacific oceans: a synthesis, Paleoceanography $1,285-311,1986$.

37 L.D. Keigwin, Towards a high-resolution chronology for latest Miocene paleoceanographic events, Paleoceanography 2, 639-660, 1987.

38 D.W. Müller and K.J. Hsü, Event stratigraphy and paleoceanography in the Fortuna basin (southeast Spain): a scenario for the Messinian salinity crisis, Paleoceanography 2, 679-696, 1987.

39 A. Decima and F.C. Wezel, Late Miocene evaporites of the central Sicilian basin, Italy, Init. Rep. DSDP 13, 1234$1240,1973$.

40 L. Beaufort and M.-P. Aubry, Fluctuations in the composition of late Miocene calcareous nannofossil assemblages as a response to orbital forcing, Paleoceanography 5, 845-865, 1990.

41 L.D. Keigwin, M.-P. Aubry and D.V. Kent, North Atlantic late Miocene stable isotope stratigraphy, biostratigraphy and magnetostratigraphy, Init. Rep. DSDP 94, 935-963, 1986.

42 M.E. Raymo, W.F. Ruddiman, J. Backman, B.M. Clement and D.G. Martinson, Late Pliocene variation in Northern Hemisphere ice sheets and North Atlantic deep water circulation, Paleoceanography 4, 413-446, 1989.

43 N.J. Shackleton, S.J. Crowhurst, N. Pisias, T. Hagelberg, D. Schneider, A. Mix and ODP Leg 138 Shipboard Scientific Party, An astronomically calibrated Pliocene time scale based on Leg 138 grape density records, 4th Int. Conf. Paleoceanogr., Abstr. Vol., p. 260, 1992.

44 L.J. Lourens, F.J. Hilgen, L. Gudjonsson and W.J. Zachariasse, Late Pliocene-early Pleistocene astronomically forced surface water productivity and temperature variations in the Mediterranean, Mar. Micropaleontol. 19, 49-78, 1992.

45 D. Rio, R. Mazzei and G. Palmieri, The stratigraphic position of the Mediterranean Upper Miocene evaporites, based on nannofossils, Mem. Soc. Geol. Ital. 16, 261-276, 1978.

46 D. Rio, R. Sprovieri and I. Raffi, Calcareous plankton biostratigraphy and biochronology of the Pliocene-lower Pleistocene succession of the Capo Rossello area, Sicily, Mar. Micropaleontol. 9, 135-180, 1984.

47 C.H. Ellis and W.H. Lohman, Neogene calcareous nannoplankton biostratigraphy in eastern Mediterranean deepsea sediments (DSDP Leg 42A, Sites 375 and 376), Mar. Micropaleontol. 4, 61-84, 1979.

48 P.W.P. Hooper and P.P.E. Weaver, Paleoceanographic significance of late Miocene to early Pliocene planktonic foraminifers at Deep Sea Drilling Project Site 609, Init. Rep. DSDP 94, 925-934, 1986.

49 C.G. Langereis and F.J. Hilgen, The Rossello composite: A Mediterranean and global reference section for the Early and early Late Pliocene, Earth Planet. Sci. Lett. 104, 211-225, 1991.

50 J.H. Linssen, Preliminary results of a study of four successive sedimentary geomagnetic reversal records from the Mediterranean, Phys. Earth Planet. Inter. 52, 207-231, 1988.

51 A.A.M. Van Hoof and C.G. Langereis, Reversal records in marine marls and delayed acquisition of remanent magnetization, Nature 351, 223-225, 1991.

52 F.J. Hilgen and C.G. Langereis, Periodicities of $\mathrm{CaCO}_{3}$ cycles in the Pliocene of Sicily: discrepancies with the quasi-periods of the Earth's orbital cycles?, Terra Nova 1, 409-415, 1989. 